\title{
Nitrogen economy in relay intercropping systems of wheat and cotton
}

\author{
L. Zhang • J. H. J. Spiertz • S. Zhang • B. Li • \\ W. van der Werf
}

Received: 10 April 2007 / Accepted: 29 September 2007 / Published online: 18 December 2007

(C) Springer Science + Business Media B.V. 2007

\begin{abstract}
Relay intercropping of wheat and cotton is practiced on a large scale in China. Winter wheat is thereby grown as a food crop from November to June and cotton as a cash crop from April to October. The crops overlap in time, growing as an intercrop, from April till June. High levels of nitrogen are applied. In this study, we analyzed the N-economy of the monocultures of cotton and wheat, and of four relay intercropping systems, differing in number of rows per strip of cotton or wheat. Field experiments were carried out from 2001/02 to 2003/04 in the Yellow
\end{abstract}

Responsible Editor: Len Wade

L. Zhang $\cdot$ S. Zhang

Cotton Research Institute, Chinese Academy of Agricultural Sciences, Key Laboratory for Genetic Improvement of Cotton, Ministry of Agriculture, Anyang, Henan 455004, China

L. Zhang

e-mail: Zhanglz@cricaas.com.cn

J. H. J. Spiertz $(\bowtie) \cdot$ W. van der Werf

Plant Sciences, Crop and Weed Ecology Group,

Wageningen University,

P.O. Box 430, 6700 AK Wageningen, The Netherlands

e-mail: huub.spiertz@wur.nl

L. Zhang $\cdot$ B. Li

College of Agricultural Resources and Environmental

Sciences, Key Laboratory of Plant and Soil Interaction,

Ministry of Agriculture, China Agricultural University,

Beijing 100094, China
River region in China. We quantified the nitrogen uptake and nitrogen use efficiency of wheat and cotton in relay intercropping systems to test if intercrops are more resource use efficient in comparison to monocrops. Nitrogen $(\mathrm{N})$ yields of wheat per unit area in the four intercropping systems were lower than in the monocrop, which ranged from 203 to $288 \mathrm{~kg} \mathrm{ha}^{-1}$. The total $\mathrm{N}$-uptake per unit biomass was similar between wheat in mono- and intercrops. On average, the N-yield of cotton per unit area was lower in intercrops than in monocrops, which ranged from 110 to $127 \mathrm{~kg} \mathrm{ha}^{-1}$, but the total $\mathrm{N}$-uptake per unit biomass was higher in intercropped cotton, as dry matter production was reduced to a greater extent by intercropping than $\mathrm{N}$-uptake. The $\mathrm{N}$-uptake of cotton was diminished during the intercropping phase, but recovered partially during later growth stages. The physiological nitrogen use efficiency (IE) of wheat was not much affected by intercropping, but it was reduced in cotton, due to delayed flowering and less reproductive growth. Total N-efficiency of the system was assessed by comparing the relative nitrogen yield total (RNT), i.e. the sum of the ratio's of total Nuptake by a component crop in the intercrop relative to the N-uptake in the monocrop, to the relative yield total. RNT ranged from 1.4 to 1.7 , while the relative yield total (RYT) ranged from 1.3 to 1.4 , indicating that intercrops used more nitrogen per unit production than monocrops. An analysis of the crop nitrogen balance showed that the nitrogen surplus of sole crops 
amounted to $220 \mathrm{~kg} \mathrm{ha}^{-1}$ for wheat and $140 \mathrm{~kg} \mathrm{ha}^{-1}$ for cotton, while in the intercropping systems, the annual $\mathrm{N}$ surplus exceeded $400 \mathrm{~kg} \mathrm{ha}^{-1}$. Conventional $\mathrm{N}$-management in intercrops thus results in high $\mathrm{N}$ surpluses that pose an environmental risk. The $\mathrm{N}$ management could be improved by means of a demand-based rate and timing of $\mathrm{N}$ applications.

Keywords $\mathrm{N}$ content $\cdot$ Internal $\mathrm{N}$ use efficiency (IE) · Crop $\mathrm{N}$ dynamics $\cdot$ Relative $\mathrm{N}$ yield total (RNT)

\section{Introduction}

Wheat-cotton relay intercropping is widely practiced by farmers in the Yellow River cotton producing region of China (Zhang et al. 2007a), because it meets the need of farmers to grow a profitable cash crop as well as to secure food supply. Relay intercropping enables the farmers to grow cotton, in a rotation with winter wheat, when the heat resource does not match the heat requirement of cotton if sown after harvesting winter wheat. The cotton is sown in April, approximately seven weeks before the harvest date of wheat. Strips are left open in the wheat crop at sowing (October/November) to provide space for the cotton plants during their seedling stage (April, May and June). After the wheat harvest in June, cotton plants can exploit the full space, above-ground as well as below-ground. A cotton-wheat relay intercropping system is thus characterized by three main phases: (1) winter wheat (vegetative stage) grown in strips from November till April; (2) intercropping of wheat (reproductive stage) and cotton (seedling stage) from April till June, and (3) sole cotton (vegetative and reproductive stage) from June till October. The two component crops in the system interact directly only during the second phase; however the physiology, ecology and productivity of the relay strip intercropping system are determined by the spatial architecture and temporal dynamics of the leaf canopy and the root systems during the whole growing cycle. There is hardly any information available on the $\mathrm{N}$ utilization and requirement of cotton and wheat in relay intercropping systems. This information is needed to develop profitable and sustainable systems.

Willey (1990) suggested that intercrops may well improve the total nutrient capture by taking up nutrients that might be leached in a monocropping system. As a result intercropping could make greater demands on the soil and thus, in the long term, intercropping yield advantages could have to be paid for with higher fertilizer inputs. Still, even though the intercropping system as a whole may consume more nitrogen, each component crop in an intercropping system is likely to take up less nitrogen than in a monocrop situation, due to competition with the other crop. This, for instance, was found by Blaise et al. (2005), who reported that total $\mathrm{N}$ uptake in strip intercropping of cotton and pigeon pea in rainfed regions of central India was lower than in sole cotton because of a lower crop productivity.

Efficiency of $\mathrm{N}$-use per each component crop is diagnosed by nitrogen use efficiency (NUE) and is commonly measured by internal (or physiological) efficiency (IE), expressed as $\mathrm{kg}$ yield per $\mathrm{kg} \mathrm{N}$ uptake (Haefele et al. 2003). Several studies show that intercrops use soil nutrients more efficiently than sole crops, because of a higher N-recovery and increased dry matter yields (Hauggaard-Nielsen et al. 2001; Zhang et al. 2004). However, agronomic N-use efficiency may also be decreased by intercropping. For instance, Aggarwal et al. (1992) found that upland rice intercropped with grain legumes took up the same amount of $\mathrm{N}$ as a monocrop, but produced significantly less dry matter.

To determine the land use advantage in terms of $\mathrm{N}$ yield for intercrops, a modification of the land equivalent ratio (Willey 1979), expressed as a relative $\mathrm{N}$ yield total (RNT) (Baumann et al. 2001) or land equivalent ratio (LER) for $\mathrm{N}$ yield (NLER) (Szumigalski and Van Acker 2006), can be employed. The RNT is calculated as the sum of the ratios of $\mathrm{N}$-uptakes by component crops in the intercrop to their respective $\mathrm{N}$-uptakes in monoculture. A value of RNT exceeding the LER suggests that intercropping is not nitrogen-efficient.

In many crops, $\mathrm{N}$ uptake is related with the accumulation of biomass and growth of leaf area over time (Booij et al. 1996; Lemaire et al. 2007). In case of $\mathrm{N}$ shortage, the actual uptake will fall short of $\mathrm{N}$ demand, and the concentration of $\mathrm{N}$ in the leaves will decrease more rapidly than in a well-fertilized crop. The robust relationships between $\mathrm{N}$ uptake, biomass accumulation and leaf area growth thus enable prediction of $\mathrm{N}$ uptake in time and provide a basis for the optimization of $\mathrm{N}$ application, both in quantity and in timing. Leigh and Johnston (1987) 
Table 1 Indicators for analysis of $\mathrm{N}$ use in relay intercropping systems and monocultures

\begin{tabular}{|c|c|c|}
\hline Indicator/symbol & Parameter & $\begin{array}{l}\text { Dimension/ } \\
\text { unit }\end{array}$ \\
\hline \multicolumn{3}{|l|}{ At crop level } \\
\hline$-\mathrm{N}$ uptake $\left(\mathrm{N}_{\mathrm{u}}\right)$ & Rate of $\mathrm{N}$ uptake per unit land area per day & $\mathrm{g} \mathrm{m}^{-2} \mathrm{~d}^{-1}$ \\
\hline \multirow[t]{3}{*}{$-\mathrm{N}$ content $\left(\mathrm{N}_{\mathrm{c}}\right)$} & $\mathrm{N}$ concentration in plant organs & $\%\left(\right.$ or $\left.\mathrm{g} \mathrm{kg}^{-1}\right)$ \\
\hline & $\mathrm{N}$ content per unit biomass & $\mathrm{kg} \mathrm{kg}^{-1}$ \\
\hline & $\mathrm{N}$ content per unit leaf area & $\mathrm{kg} \mathrm{m}^{-2}$ \\
\hline$-\mathrm{SLN}$ & Specific leaf $\mathrm{N}$ content per unit leaf area & $\mathrm{g} \mathrm{m}^{-2}$ \\
\hline$-\mathrm{N}$ yield $\left(\mathrm{N}_{\mathrm{y}}\right)$ & Total $\mathrm{N}$ uptake per unit land area at final harvest & $\mathrm{kg} \mathrm{ha}^{-1}$ \\
\hline $\begin{array}{l}\text {-Nitrogen use efficiency (NUE) expressed } \\
\text { as Internal efficiency (IE) }\end{array}$ & $\begin{array}{l}\mathrm{N} \text { utilization efficiency for grain or lint production; } \\
\mathrm{kg} \text { grain or lint per } \mathrm{kg} \mathrm{N} \text { uptake }\end{array}$ & $\mathrm{kg} \mathrm{kg}^{-1}$ \\
\hline \multicolumn{3}{|l|}{ At system level } \\
\hline -Relative N yield total (RNT) & Combined $\mathrm{N}$ yield of intercrops relative to the monocrops & None \\
\hline$-\mathrm{N}$ balance & $\mathrm{N}$ input minus $\mathrm{N}$ output & $\mathrm{kg} \mathrm{ha}^{-1}$ \\
\hline
\end{tabular}

All indicators except RNT and N balance are per crop species.

suggested a close association between leaf $\mathrm{N}$ concentration, rate of photosynthesis and biomass growth. To assess the balance between $\mathrm{N}$ uptake and demand, and to diagnose $\mathrm{N}$ deficiency the observed $\mathrm{N}$ dilution in the biomass can be compared to the minimal concentration of $\mathrm{N}$ in shoots necessary to produce the maximum dry mass (Justes et al. 1994). The trend in $\mathrm{N}$ dilution with increasing biomass can be represented by a power relationship (Flenet et al. 2006). The $\mathrm{N}$ dilution curve can be used to diagnose $\mathrm{N}$ deficiency, to manage $\mathrm{N}$ fertilization and for modeling $\mathrm{N}$ allocation (Lemaire et al. 2007). N dilution curves have been widely studied for monocrops but not for crops in intercropping systems. Considering the relatively high cost of nitrogen $(\mathrm{N})$ fertilizer, and environmental concerns associated with excessive $\mathrm{N}$ application, increasing the $\mathrm{N}$ use efficiency of cropping systems is needed urgently.

The N-economy of a crop is the result of many processes occurring in the soil, crop and atmosphere and can be quantified by a wide variety of parameters (Peng and Bouman 2007; Spiertz and Vos 2005). In this study, we determined N-uptake in relation to DMyield, physiological $\mathrm{N}$ use efficiency, and $\mathrm{N}$-dilution in biomass over time. Furthermore, a nitrogen balance sheet analysis was made based on estimates of $\mathrm{N}$ input and -output in the systems. We used different indicators at the crop and system level to analyze the nitrogen economy and use efficiency (Table 1).
The specific objectives are: (a) to quantify the nitrogen uptake and nitrogen use efficiency of wheat and cotton in relay intercropping systems; (b) to determine the relationships between $\mathrm{N}$ uptake and accumulation of biomass and growth of leaf area; (c) to quantify $\mathrm{N}$ dynamics of cotton in relation to the effects of intercropping; and (d) to explore the opportunities for a more effective nitrogen management of wheat-cotton intercropping systems.

\section{Materials and methods}

Field experiments

Field experiments were conducted in 2001/02, 2002/03 and 2003/04 consecutively on the same field at the Cotton Research Institute of Chinese Academy of Agricultural Sciences (CRI, CAAS), Anyang city, Henan province, China at $36^{\circ} 07^{\prime}$ North and $116^{\circ} 22^{\prime}$ East.

Soil parameters of the field are: sandy loam, $\mathrm{pH}$ 8.0 , bulk density $1.36 \mathrm{~g} \mathrm{~cm}^{-3}$, and organic matter content $13.2 \mathrm{~g} \mathrm{~kg}^{-1}$. At the start of the experiments, in October 2001, the soil contained $1.02 \mathrm{~g} \mathrm{~kg}^{-1}$ total $\mathrm{N}$, $0.52 \mathrm{~g} \mathrm{~kg}^{-1} \mathrm{P}$ and $17.3 \mathrm{~g} \mathrm{~kg}^{-1} \mathrm{~K}$. The amount of precipitation in 2002, 2003 and 2004 was 318, 539 and $517 \mathrm{~mm}$, respectively.

For details on crop development we refer to Zhang et al. (2007b) 


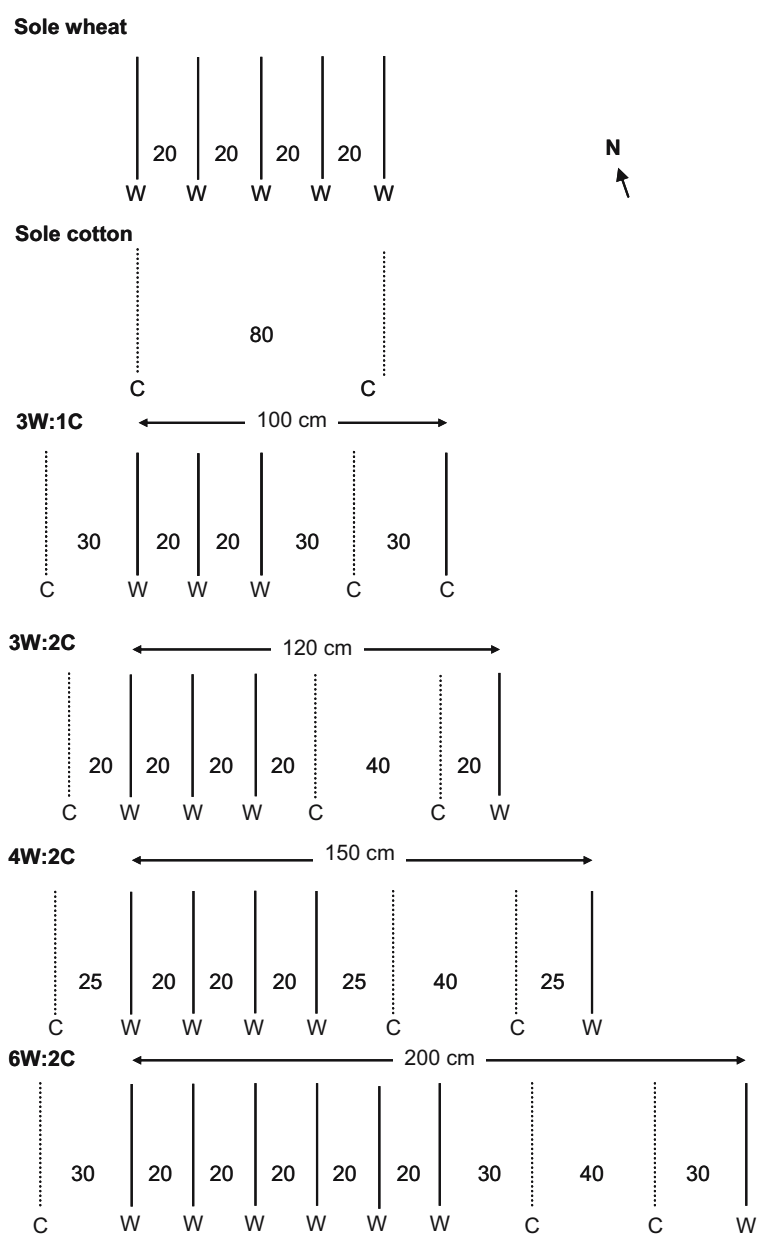

Fig. 1 Layout of wheat-cotton intercropping systems and monocultures (reproduced with permission from Zhang et al. 2007a). In the sole wheat crop, the row distance is $20 \mathrm{~cm}$, and in the sole cotton crop, row distance is $80 \mathrm{~cm}$. The sole crops do not have a strip structure. Intercrops, on the contrary, do have a strip structure, with strips of one or more crop rows of wheat and cotton alternating. The 3:1 system, for example, alternates strips of three wheat rows (sown at $20 \mathrm{~cm}$ distance from each other) with single rows of cotton. The distance between the cotton and wheat rows in this system is $30 \mathrm{~cm}$. The $3: 2$ system uses the same design for the wheat strip, but it has a wider path in which two rows of cotton are sown. The distance between the cotton rows is $40 \mathrm{~cm}$, and the distance between wheat and cotton rows is $20 \mathrm{~cm}$. In the $4: 2$ system, there are 4 wheat rows per strip, and there is $25 \mathrm{~cm}$ between the cotton and wheat rows. In the $6: 2$ system, there are 6 wheat rows per strip, and there is $30 \mathrm{~cm}$ between cotton and wheat rows

\section{Experiment 1: $N$ economy of intercropping and monoculture systems}

This experiment was conducted in 2001/02, 2002/03 and 2003/04, and comprised six treatments including four different intercropping patterns and monocultures of wheat (Triticum aestivum L.) and cotton (Gossypium hirsutum L.). The four intercropping patterns were all strip intercrops, with strips of cotton and wheat alternating. The number of wheat $v s$. cotton rows per strip in the four systems was $3: 1,3: 2$, $4: 2$ and 6:2. Row distance in wheat was $20 \mathrm{~cm}$ and between cotton rows $40 \mathrm{~cm}$, but distance between cotton and wheat was varied (Fig. 1). The experimental systems are characterized by the width of a "minimal combination," i.e. an adjacent wheat and cotton strip, the row length density (total row length per $\mathrm{m}^{2}$, or simply the number of rows per $\mathrm{m}$, expressed over the whole intercropped area) and homogenized densities, i.e. densities of either crop, expressed per unit total intercrop area (Table 2).

The six treatments were arranged in four randomized blocks with a plot size of $180 \mathrm{~m}^{2}$. Wheat was sown on 4 November 2001, 2 November 2002 and 3 November 2003. Cotton was sown on 26 April 2002, 25 April 2003 and 25 April 2004. The wheat cultivar was 'Zhongyu 5' and cotton cultivars were middle maturing upland Bt cotton 'Shiyuan 321' in 2002 and the Verticillium-tolerant variety 'CCRI45' in 2003 and 2004.

Irrigation water was applied by flooding $(350 \mathrm{~mm})$ in 2002 and by drip application in 2003 (342 mm) and $2004(182 \mathrm{~mm})$. The total amount of nitrogen applied to wheat and cotton ranged from 302 to $412 \mathrm{~kg} \mathrm{~N}^{-1} \mathrm{y}^{-1}$. Information on amount, composition and application dates of fertilizer materials is provided in Table 3. Fertilizers were applied evenly over the whole area of the plots, not discriminating between crop strips and paths.

\section{Experiment 2: Response of the intercropping system to nitrogen input}

The response of the 3:2 relay intercropping system to three nitrogen doses was investigated in 2002/03 and 2003/04. Cultivars and planting dates were the same as in Expt 1, but the minimum combination width was $20 \mathrm{~cm}$ wider. The amount of irrigation water was $177 \mathrm{~mm}$ over the whole wheat and cotton growing period. As in Experiment 1, fertilizer doses were applied evenly on strips with and without a crop. Nitrogen was applied at full dose $\left(180 \mathrm{~kg} \mathrm{ha}^{-1}\right)$, at half dose, and at $150 \%$ dose. Before wheat was sown in $2002,57 \mathrm{~kg} \mathrm{~N}^{-1}$ was applied as cotton seed cake and $47 \mathrm{~kg} \mathrm{~N} \mathrm{ha}^{-1}$ as compound fertilizer; no base 
Table 2 Characteristics of relay intercropping systems and monocultures (Exp. 1)

\begin{tabular}{|c|c|c|c|c|c|}
\hline \multirow[t]{2}{*}{ Cropping system } & \multirow[t]{2}{*}{ Total width $(\mathrm{m})^{\mathrm{a}}$} & \multicolumn{2}{|c|}{ Row length density ${ }^{\mathrm{b}}\left(\mathrm{m} \mathrm{m}^{-2}\right)$} & \multicolumn{2}{|c|}{ Homogenized density ${ }^{c}\left(\# \mathrm{~m}^{-2}\right)$} \\
\hline & & Wheat & Cotton & Wheat & Cotton \\
\hline $3: 1$ & 1 & 3 & 1 & $524 \pm 18$ & $4.9 \pm 0.11$ \\
\hline $3: 2$ & 1.2 & 2.5 & 1.67 & $425 \pm 26$ & $7.5 \pm 0.22$ \\
\hline $4: 2$ & 1.5 & 2.67 & 1.33 & $495 \pm 27$ & $6.3 \pm 0.20$ \\
\hline $6: 2$ & 2.0 & 3 & 1 & $471 \pm 22$ & $4.7 \pm 0.11$ \\
\hline Sole wheat & 0.2 & 5 & - & $725 \pm 28$ & - \\
\hline Sole cotton & 0.8 & - & 1.25 & - & $6.1 \pm 0.16$ \\
\hline
\end{tabular}

${ }^{\mathrm{a}}$ Total width refers to the minimum width of a combination of components crops ( $c f$ Fig. 1).

${ }^{\mathrm{b}}$ Row length density is the total row length of a component crop per unit area $\left(\mathrm{m} \mathrm{m}^{-2}\right.$ or rows $\left.\mathrm{m}^{-1}\right)$.

${ }^{\mathrm{c}}$ Homogenized density is the number of ears per $\mathrm{m}^{2}$ for wheat averaged for 2003 and 2004 and number of plants per $\mathrm{m}^{2}$ for cotton averaged from 2002 and 2004.

fertilizer was applied in 2003. During the growing season, urea $(46 \% \mathrm{~N})$ was applied on wheat and cotton by drip irrigation according to the designated dose level $(50,100$ or $150 \%)$.

\section{Measurements}

To determine crop yields, plants were harvested at maturity in each plot; the sampling area covered $5 \mathrm{~m}$ row length by $2 \mathrm{~m}$ width in the 3:1 system, $5 \mathrm{~m}$ length by $2.4 \mathrm{~m}$ width in the $3: 2$ system, $3.5 \mathrm{~m}$ row length by $3 \mathrm{~m}$ width in the $4: 2$ system and $5 \mathrm{~m}$ row length by $2 \mathrm{~m}$ width in the $6: 2$ system.

To assess above-ground dry mass (DM) and nitrogen uptake, $1 \mathrm{~m}$ row of each plot was sampled once per 2 weeks. First the number of plants was counted; next a sub-sample was selected for analysis. The subsamples consisted of twenty randomly selected

Table 3 Type, amount and timing of nitrogen applied in Exp. 1

\begin{tabular}{|c|c|c|c|}
\hline \multirow[t]{2}{*}{ Nitrogen source ${ }^{1}$} & \multicolumn{3}{|c|}{ Nitrogen applied $\left(\mathrm{kg} \mathrm{N} \mathrm{ha}^{-1}\right)$} \\
\hline & $2001 / 2002$ & $2002 / 2003$ & $2003 / 2004$ \\
\hline \multicolumn{4}{|l|}{ Organic material } \\
\hline Natural dried dung & $20(\mathrm{BS})^{2}$ & - & - \\
\hline Cottonseed cake & $46(\mathrm{BS})$ & $57(\mathrm{BS})$ & - \\
\hline Subtotal & 66 & 57 & - \\
\hline \multicolumn{4}{|l|}{ Fertilizers } \\
\hline \multicolumn{4}{|l|}{-Wheat growing season } \\
\hline Compound fertilizer & $53(\mathrm{BS})$ & 47 (BS) & $100(\mathrm{BS})$ \\
\hline Ammonium phosphate & $50(\mathrm{BS})$ & - & - \\
\hline Urea & 30 (Dec 17) & 77 (Mar 29) & 111 (Feb 17) \\
\hline Urea & $26($ Feb 23) & & \\
\hline Subtotal & 159 & 124 & 211 \\
\hline \multicolumn{4}{|l|}{-Cotton growing season } \\
\hline Ammonium phosphate & 20 (June 17) & - & - \\
\hline Urea & 77 (June 17) & 52 (June 20) & 51 (June 12) \\
\hline Urea & 90 (July 22) & 69 (July 14) & 96 (July 8) \\
\hline Subtotal & 187 & 121 & 147 \\
\hline Total organic and fertilizer $\mathrm{N}$ & 412 & 302 & 358 \\
\hline
\end{tabular}

${ }^{1}$ Nutrient contents: $1.1 \% \mathrm{~N}, 0.3 \% \mathrm{P}, 1.2 \% \mathrm{~K}$ for dried dung, $4.3 \% \mathrm{~N}, 0.5 \% \mathrm{P}, 0.8 \% \mathrm{~K}$ for cotton seed cake $12 \% \mathrm{~N}, 28 \% \mathrm{P}_{2} \mathrm{O}_{5}$, $15 \% \mathrm{~K}_{2} \mathrm{O}$ for compound fertilizer, $18 \% \mathrm{~N}, 46 \% \mathrm{P}_{2} \mathrm{O}_{5}$ for ammonium phosphate, and $46 \% \mathrm{~N}$ for urea.

${ }^{2}$ Dates in brackets are dates of application; BS indicates before sowing 
wheat plants, and in the case of cotton of 10 seedlings, or, later on, three plants.

The leaf area of the subsampled cotton plants was determined by measuring length and width of individual leaves, and using the formula (Zhang, unpublished):

leaf area $=0.810 \times$ length $\times$ width

The samples were subsequently oven-dried at $65^{\circ} \mathrm{C}$ to determine dry matter weight.

Nitrogen content of plant and soil samples was determined by the Micro-Kjeldahl method (Ogg 1960). Leaves and stems were weighted and analysed separately in 2002. In 2003 and 2004, analyses were made using the total vegetative aboveground biomass. $\mathrm{N}$-content of reproductive organs (i.e. the spike of wheat and the squares, flowers and bolls of cotton) was determined separately.

Soil samples were taken before wheat sowing in October 2001, 2002 and 2003, taking five samples per plot with a $3 \mathrm{~cm}$ diameter auger. Soil samples from 0-30 $\mathrm{cm}$ depth and from $30-60 \mathrm{~cm}$ depth was analysed separately.
Data analysis

\section{Nitrogen use efficiency}

Internal efficiency of nitrogen use (IE) is defined as:

$\mathrm{IE}_{i}=\frac{Y_{i}}{\mathrm{~N}_{i}}$

Where $Y_{i}$ is the yield of crop $i$ (g harvestable product $\mathrm{m}^{-2}$ ) and $\mathrm{N}_{i}$ is nitrogen uptake ( $\mathrm{g}$ total $\mathrm{N}$ uptake $\mathrm{m}^{-2}$ ) by crop $i$.

\section{Relative nitrogen yield}

The relative nitrogen uptake is calculated as:

$\mathrm{RNT}=\mathrm{RNW}+\mathrm{RNC}=\frac{\mathrm{N}_{\mathrm{W}, \mathrm{I}}}{\mathrm{N}_{\mathrm{W}, \mathrm{S}}}+\frac{\mathrm{N}_{\mathrm{C}, \mathrm{I}}}{\mathrm{N}_{\mathrm{C}, \mathrm{S}}}$

In this equation RNW and $\mathrm{RNC}$ are the relative values for wheat and cotton $\mathrm{N}$ yield, respectively. $\mathrm{N}_{\mathrm{W}, \mathrm{I}}$, $\mathrm{N}_{\mathrm{W}, \mathrm{S}}, \mathrm{N}_{\mathrm{C}, \mathrm{I}}$ and $\mathrm{N}_{\mathrm{C}, \mathrm{S}}$ represent nitrogen uptake of intercropped and sole wheat, and of intercropped and sole cotton, respectively.

Table 4 Homogenized yield, harvest index (HI), nitrogen yield and Internal use efficiency (IE) for three cropping cycles (Exp. 1)

\begin{tabular}{|c|c|c|c|c|c|c|c|c|}
\hline \multirow{2}{*}{ Cropping pattern } & \multirow{2}{*}{$\frac{\text { Wheat }}{\text { Grain } \mathrm{g} \mathrm{m}^{-2}}$} & \multicolumn{7}{|l|}{ Cotton } \\
\hline & & $\mathrm{HI} g \mathrm{~g}^{-1}$ & $\mathrm{~N}$ yield $\mathrm{g} \mathrm{m}^{-2}$ & IE $g g^{-1}$ & Lint $\mathrm{g} \mathrm{m}^{-2}$ & $\mathrm{HI} \mathrm{g} \mathrm{g}^{-1}$ & $\mathrm{~N}$ yield $\mathrm{g} \mathrm{m}^{-2}$ & IE $\mathrm{g} \mathrm{gN}^{-1}$ \\
\hline \multicolumn{9}{|l|}{$-2001 / 2002-$} \\
\hline $3: 1$ & $551.5 \mathrm{a}$ & $0.45 \mathrm{a}$ & $19.9 \mathrm{a}$ & $27.9 \mathrm{a}$ & $60.4 \mathrm{a}$ & $0.12 \mathrm{a}$ & $13.7 \mathrm{a}$ & $4.5 \mathrm{a}$ \\
\hline $3: 2$ & $500.1 \mathrm{~b}$ & $0.45 \mathrm{a}$ & $17.8 \mathrm{a}$ & $28.0 \mathrm{a}$ & $66.0 \mathrm{a}$ & $0.14 \mathrm{ab}$ & $14.0 \mathrm{a}$ & $5.5 \mathrm{a}$ \\
\hline $4: 2$ & $475.8 \mathrm{~b}$ & $0.43 \mathrm{a}$ & $18.6 \mathrm{a}$ & $26.1 \mathrm{a}$ & $77.4 \mathrm{a}$ & $0.13 \mathrm{a}$ & $13.2 \mathrm{a}$ & $6.1 \mathrm{a}$ \\
\hline $6: 2$ & $514.4 \mathrm{ab}$ & $0.44 \mathrm{a}$ & $19.7 \mathrm{a}$ & $26.2 \mathrm{a}$ & $60.9 \mathrm{a}$ & $0.12 \mathrm{a}$ & $12.0 \mathrm{a}$ & $5.1 \mathrm{a}$ \\
\hline Monoculture & $760.7 \mathrm{c}$ & $0.39 \mathrm{a}$ & $28.8 \mathrm{~b}$ & $27.7 \mathrm{a}$ & $115.2 \mathrm{~b}$ & $0.20 \mathrm{~b}$ & $12.7 \mathrm{a}$ & $9.7 \mathrm{~b}$ \\
\hline SE & 15.0 & 0.02 & 0.9 & 1.7 & 6.1 & 0.02 & 2.0 & 1.0 \\
\hline \multicolumn{9}{|l|}{$-2002 / 2003-$} \\
\hline $3: 1$ & $415.6 \mathrm{a}$ & $0.40 \mathrm{a}$ & $17.1 \mathrm{ac}$ & $24.4 \mathrm{a}$ & $57.4 \mathrm{a}$ & $0.16 \mathrm{a}$ & $7.9 \mathrm{ab}$ & $7.3 \mathrm{a}$ \\
\hline $3: 2$ & $362.0 \mathrm{~b}$ & $0.43 \mathrm{a}$ & $13.0 \mathrm{~b}$ & $28.0 \mathrm{a}$ & $67.0 \mathrm{a}$ & $0.17 \mathrm{a}$ & $9.7 \mathrm{ac}$ & $7.2 \mathrm{a}$ \\
\hline $4: 2$ & $391.7 \mathrm{ab}$ & $0.47 \mathrm{a}$ & $14.7 \mathrm{bc}$ & $26.8 \mathrm{a}$ & $58.1 \mathrm{a}$ & $0.15 \mathrm{a}$ & $10.1 \mathrm{ac}$ & $5.8 \mathrm{a}$ \\
\hline $6: 2$ & $395.3 \mathrm{ab}$ & $0.46 \mathrm{a}$ & $16.2 \mathrm{c}$ & $24.7 \mathrm{a}$ & $49.2 \mathrm{a}$ & $0.17 \mathrm{a}$ & $5.2 \mathrm{~b}$ & $9.4 \mathrm{a}$ \\
\hline Monoculture & $520.8 \mathrm{c}$ & $0.45 \mathrm{a}$ & $20.3 \mathrm{~d}$ & $25.7 \mathrm{a}$ & $93.3 \mathrm{~b}$ & $0.20 \mathrm{a}$ & $11.0 \mathrm{c}$ & $9.4 \mathrm{a}$ \\
\hline SE & 11.4 & 0.03 & 0.7 & 1.5 & 7.5 & 0.03 & 0.9 & 1.5 \\
\hline \multicolumn{9}{|l|}{$-2003 / 2004-$} \\
\hline $3: 1$ & $584.8 \mathrm{a}$ & $0.45 \mathrm{ab}$ & $20.5 \mathrm{a}$ & $29.0 \mathrm{a}$ & $69.5 \mathrm{ab}$ & $0.16 \mathrm{a}$ & $10.0 \mathrm{a}$ & $7.3 \mathrm{a}$ \\
\hline $3: 2$ & $513.3 \mathrm{~b}$ & $0.46 \mathrm{a}$ & $17.0 \mathrm{~b}$ & $30.9 \mathrm{~b}$ & $90.2 \mathrm{a}$ & $0.18 \mathrm{a}$ & $12.2 \mathrm{~b}$ & $7.4 \mathrm{ab}$ \\
\hline $4: 2$ & $502.3 \mathrm{~b}$ & $0.44 \mathrm{ab}$ & $18.8 \mathrm{ab}$ & $26.8 \mathrm{a}$ & $87.4 \mathrm{ab}$ & $0.22 \mathrm{a}$ & $8.5 \mathrm{a}$ & $10.5 \mathrm{~b}$ \\
\hline $6: 2$ & $515.8 \mathrm{~b}$ & $0.49 \mathrm{a}$ & $17.4 \mathrm{ab}$ & $29.7 \mathrm{a}$ & $65.6 \mathrm{~b}$ & $0.21 \mathrm{a}$ & $6.5 \mathrm{c}$ & $10.1 \mathrm{ab}$ \\
\hline Monoculture & $682.9 \mathrm{c}$ & $0.39 \mathrm{~b}$ & $26.9 \mathrm{c}$ & $25.5 \mathrm{a}$ & $117.0 \mathrm{c}$ & $0.20 \mathrm{a}$ & $11.7 \mathrm{~b}$ & $10.0 \mathrm{ab}$ \\
\hline SE & 14.5 & 0.02 & 1.0 & 1.6 & 7.4 & 0.02 & 0.5 & 1.0 \\
\hline
\end{tabular}

a, b and c: a common letter in one column subdivision means no significant difference at $\operatorname{LSD}_{0.05}$.

$\mathrm{N}$ yield indicates the total nitrogen uptake of cotton at the open boll stage. 


\section{Nitrogen dilution effect}

The $\mathrm{N}$ dilution curve is described using a power function (Flenet et al. 2006):

$\mathrm{N} \%=a_{\mathrm{c}} W^{b_{\mathrm{c}}}$

where $\mathrm{N} \%$ is nitrogen concentration, $W$ is aboveground dry mass, $a_{\mathrm{c}}$ is the $\mathrm{N}$ percentage at $W=1 \mathrm{~g}$ $\mathrm{m}^{-2}$ and $b_{\mathrm{c}}$ is a curvature parameter.

Statistical analysis

Data on grain and lint yield, harvest index, nitrogen content, and total nitrogen uptake were analysed by ANOVA in SPSS 11.0, using a randomized block design with cropping system as fixed effect. Least significant differences (LSD) were used to separate treatment means $(P<0.05)$.

\section{Results}

Crop yields and total N-uptake

Crop yields, harvest indices and total nitrogen uptake by the intercropped wheat and cotton, compared to monocultures, are shown in Table 4. The nitrogen yield of wheat in the intercropping systems ranged from 130 to $205 \mathrm{~kg} \mathrm{ha}^{-1}$, which was significantly lower $(P<0.01)$ than the 3-year's average $\mathrm{N}$ yield of sole wheat $\left(253 \mathrm{~kg} \mathrm{ha}^{-1}\right)$. Intercropping reduced the
Fig. 2 RNT, relative N yield total (a, c and e) and LER, relative agronomic yield (b, $\mathbf{d}$ and $\mathbf{f}$ ) of wheat and cotton in the intercropping systems, in three years experimentation. SE's pertain to the contributions of wheat and cotton to the RNT and LER
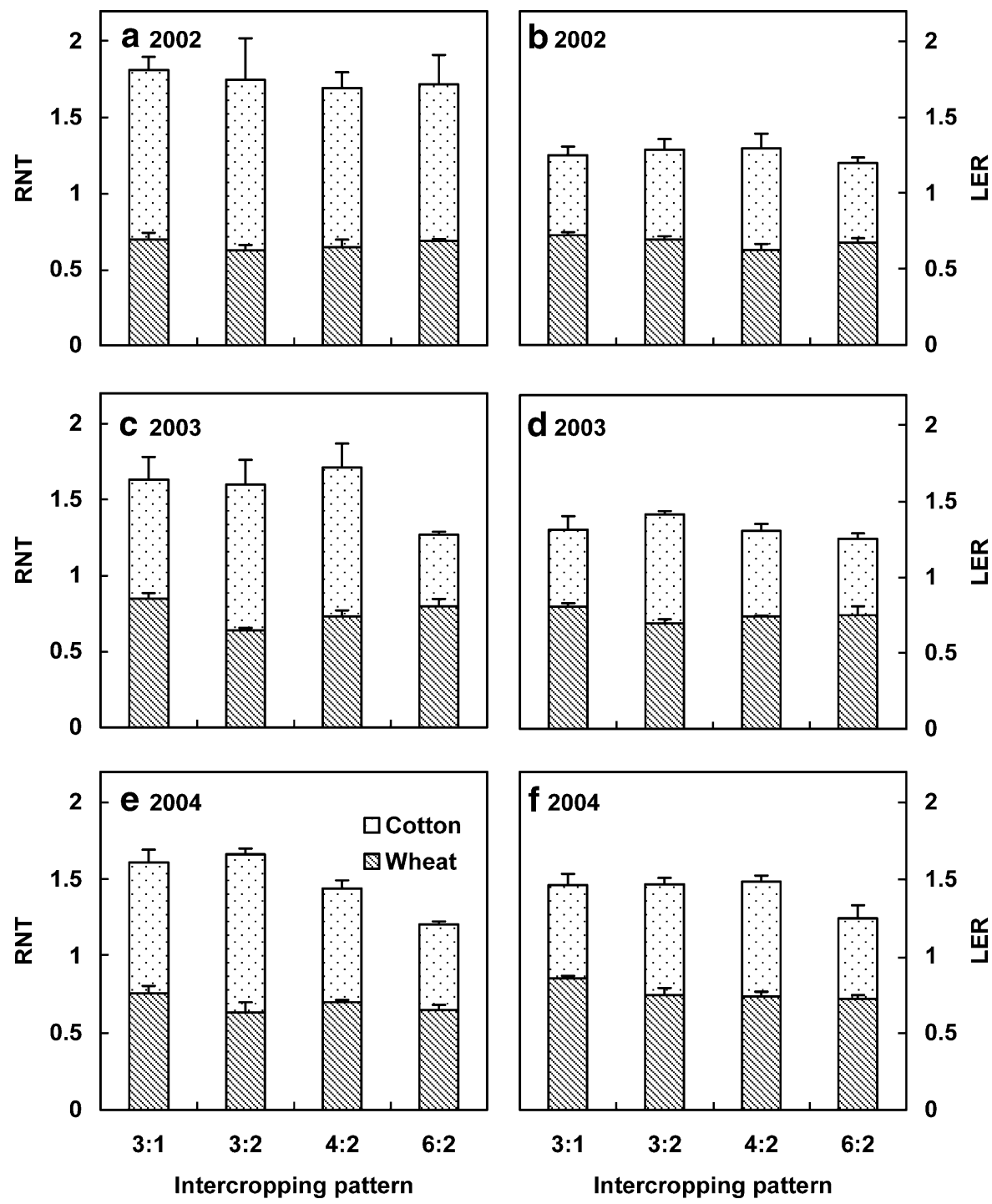
Table 5 Homogenized yield, above-ground dry mass (DM) and nitrogen uptake $\left(\mathrm{N}_{\mathrm{u}}\right)$ under different $\mathrm{N}$ application rates $\left(\mathrm{N}_{\mathrm{a}}\right)$ in the $3: 2$ system (Exp. 2)

\begin{tabular}{|c|c|c|c|c|c|c|c|c|c|}
\hline \multicolumn{5}{|l|}{ Wheat } & \multicolumn{5}{|l|}{ Cotton } \\
\hline $\mathrm{N}_{\mathrm{a}}$ & Yield $^{\mathrm{a}}$ & $\mathrm{DM}$ & $\mathrm{N}_{\mathrm{u}}$ & IE & $\mathrm{N}_{\mathrm{a}}$ & Yield $^{\mathrm{b}}$ & $\mathrm{DM}$ & $\mathrm{N}_{\mathrm{u}}$ & IE \\
\hline $\mathrm{g} \mathrm{m}^{-2}$ & $\mathrm{~g} \mathrm{~m}^{-2}$ & $\mathrm{~g} \mathrm{~m}^{-2}$ & $\mathrm{~g} \mathrm{~m}^{-2}$ & $\mathrm{~g} \mathrm{gN}^{-1}$ & $\mathrm{~g} \mathrm{~m}^{-2}$ & $\mathrm{~g} \mathrm{~m}^{-2}$ & $\mathrm{~g} \mathrm{~m}^{-2}$ & $\mathrm{~g} \mathrm{~m}^{-2}$ & $\mathrm{~g} \mathrm{gN}^{-1}$ \\
\hline \multicolumn{10}{|c|}{$-2002 / 2003-$} \\
\hline 14.1 & 350 & 730 & 13.9 & 26.0 & 5.3 & 61.0 & 417 & 7.9 & 7.6 \\
\hline 17.8 & 369 & 724 & 14.8 & 25.0 & 10.5 & 62.2 & 399 & 8.1 & 7.7 \\
\hline 25.3 & 333 & 747 & 13.7 & 24.7 & 21.0 & 51.2 & 363 & 7.9 & 6.5 \\
\hline SE & 6 & 35 & 1.4 & 2.5 & - & 7.1 & 21 & 0.5 & 0.8 \\
\hline \multicolumn{10}{|c|}{$-2003 / 2004-$} \\
\hline 3.8 & 369 & 693 & 12.0 & 32.7 & 5.3 & 99.6 & 567 & 9.1 & 11.2 \\
\hline 7.5 & 385 & 713 & 10.7 & 36.0 & 10.5 & 96.9 & 491 & 9.2 & 10.5 \\
\hline 15.0 & 375 & 772 & 11.9 & 31.5 & 21.0 & 98.2 & 454 & 7.7 & 12.9 \\
\hline SE & 28 & 33 & 1.2 & 3.5 & - & 4.3 & 48 & 0.7 & 0.9 \\
\hline
\end{tabular}

The experiment was irrigated and fertilized by drip irrigation after June 2003; the total amount of water including rainfall was $717 \mathrm{~mm}$ in 2002/03 and $693 \mathrm{~mm}$ in 2003/04.

${ }^{1}$ Yield of wheat is based on grain weight with $12 \%$ water content.

${ }^{2}$ Yield of cotton in lint dry weight.

nitrogen yield of wheat proportionally to grain yield, reflecting mainly the differences in homogenized plant densities. The reduction in nitrogen yield of wheat by intercropping was greatest in the $3: 2$ and $4: 2$ systems, and smallest in the 3:1 system. The response of the $6: 2$ system varied between years.

The effect of intercropping on nitrogen uptake of cotton differed between years. In 2002, the nitrogen yield of cotton in intercrops ranged from 120 to $140 \mathrm{~kg} \mathrm{ha}^{-1}$ compared to an $\mathrm{N}$ yield in the monoculture of $127 \mathrm{~kg} \mathrm{ha}^{-1}$, with no significant difference $(P>0.05)$ between the monocrop and intercrops. However, in 2003 and 2004, cotton $\mathrm{N}$ yields in intercrops were significantly lower than in monocrops, except for the 3:2 system. Especially, the total $\mathrm{N}$ uptake of cotton in the 6:2 system was extremely low (Table 4), which was caused by an incomplete canopy closure and low biomass and lint yield.

The relative nitrogen yield of cotton (RNC) in intercropping systems was much higher than the relative lint yield (RYC), indicating that the lint yield was much more diminished by intercropping than nitrogen uptake (Fig. 2). RNC values did not differ significantly among the intercropping patterns $3: 2,4: 2$ and $3: 1$; but the value was significantly lower for the $6: 2$ system $(P<$
0.05). For wheat there were hardly any differences between the relative nitrogen yield of wheat (RNW) and the relative grain yield of wheat (RYW) (Fig. 2). Both parameters, RNW and RYW, were closely associated with row length densities (total row length of one crop species per $\mathrm{m}^{2}$, averaged over the whole field, $\mathrm{m} \mathrm{m}^{-2}$ ). The values were somewhat higher in the $3: 1$ and $6: 2$ systems and lower in the 3:2 system.

$\mathrm{N}$-use efficiency of wheat and cotton

The physiological nitrogen use efficiencies (IE) of wheat varied from 24.4 to $30.9 \mathrm{~kg}$ grain per $\mathrm{kg} \mathrm{N}$ uptake for intercrops and from 25.5 to $27.7 \mathrm{~kg} \mathrm{~kg}^{-1}$ for the monocrop. In 2002 and 2003, the IE of wheat was not significantly affected by intercropping (Table 4), but in 2004, wheat in the 3:2 system showed a significant higher IE-value than in the other systems including the monocrop.

The effect of intercropping on the IE of cotton varied between years. In 2002, it ranged from 4.5 to $6.1 \mathrm{~kg}$ lint per $\mathrm{kg} \mathrm{N}$ uptake in intercropping systems, which was significantly $(\mathrm{P}<0.02)$ lower than in sole cotton $\left(9.7 \mathrm{~kg} \mathrm{~kg}^{-1}\right)$. Due to the large variation, IE did not significantly differ between systems in 2003 and 

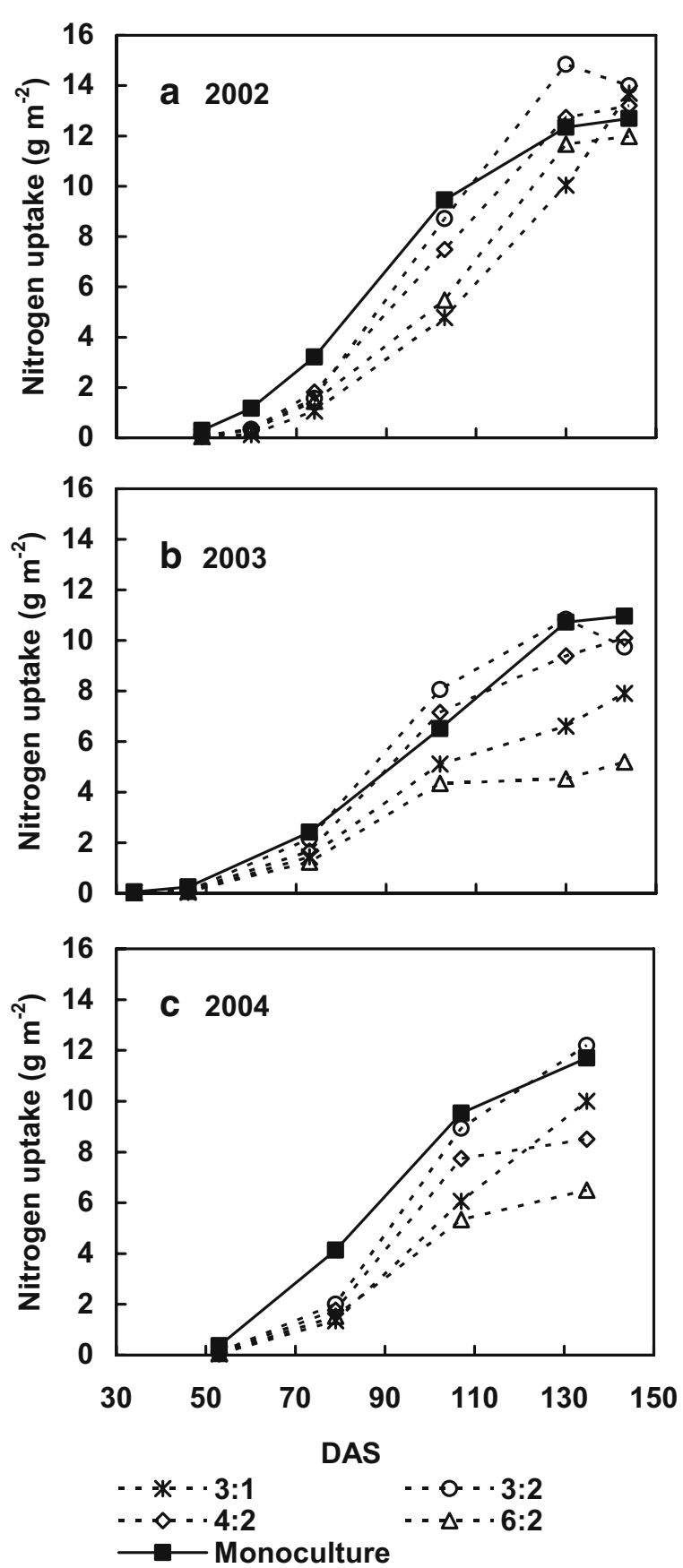

Fig. 3 Nitrogen uptake by cotton in the intercropping systems and the monoculture in 2002-2004

2004. Averaged over 3 years, the IE values amounted to $6.4,6.7,7.5,8.2$ and 9.7 for the $3: 1,3: 2,4: 2,6: 2$ systems and the monoculture, respectively. Lower IE's of cotton in intercrops, compared to monoculture, were mainly due to lower DM accumulation and lower (15-30\%) harvest indexes (HI).
Crop yields and total N-uptake under reduced input

In Experiment $2(2002 / 2003$ and 2003/2004), the nitrogen fertilizer input to a 3:2 intercrop was varied between 38 and $150 \mathrm{~kg} \mathrm{ha}^{-1}$ during the wheat phase and between 53 and $210 \mathrm{~kg} \mathrm{ha}^{-1}$ during the cotton phase in intercropping systems. Grain yields of wheat were somewhat lower under the highest nitrogen application rate $\left(210 \mathrm{~kg} \mathrm{ha}^{-1}\right)$ than with the other two $\mathrm{N}$-inputs, due to a lower $\mathrm{HI}$ at higher $\mathrm{N}$-input (Table 5). Lint yields of cotton differed strongly between the two seasons, however, did not respond to the reduced N-rates. Despite the substantial difference in $\mathrm{N}$-inputs between treatments, the uptake of nitrogen did not differ significantly (Table 5), indicating ample soil N-reserves. Estimated apparent $\mathrm{N}$ recoveries in 2002/2003 and 2003/2004 amounted to 115 and $141 \mathrm{~kg} \mathrm{ha}^{-1}$ in the wheat crop, and 80 and $87 \mathrm{~kg} \mathrm{ha}^{-1}$ in the cotton crop. Thus matching most of the $\mathrm{N}$ requirement of both crops.

Cotton nitrogen dynamics

During the early growth stages, nitrogen uptake was slower in intercropped cotton than in the monocrop (Fig. 3), but uptake caught up in intercrops from 80 days after sowing (DAS). N-uptake leveled off from 110 DAS. In all the 3 years, the rate of $\mathrm{N}$-uptake was most fast and total $\mathrm{N}$-uptake reached the highest level in the 3:2 system and both were lowest in the $6: 2$ system. In each of the years, cotton in the 3:1 system had a low rate of N-uptake early on, but cotton in this system

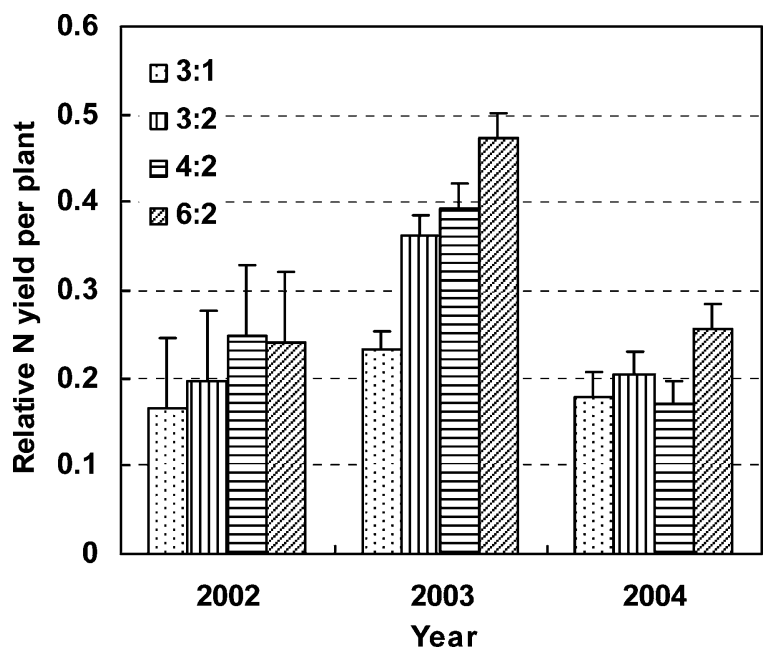

Fig. 4 Relative nitrogen yield of cotton per plant in the intercropping systems at the time of wheat harvest in 2002-2004 


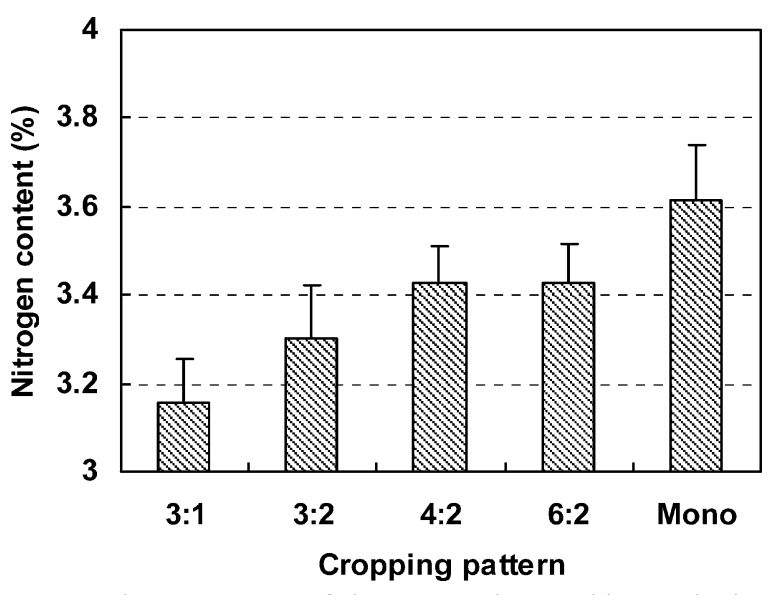

Fig. 5 Nitrogen content of above-ground cotton biomass in the intercropping systems and the monoculture at the time of the wheat harvest in 2002-2004

accumulated $\mathrm{N}$ at the fastest rate of all systems at the end of the season. Cotton in the 4:2 system showed similar patterns of N-uptake as cotton in the 3:2 system, but at a somewhat slower rate and lower final level, reflecting the lower density of cotton plants in this system, compared to the 3:2 system (Table 2). Likewise, the low level of nitrogen uptake in the 6:2 system can be explained by the lower canopy density and biomass yield in comparison to other systems (Tables 2 and 4).

Major influences of intercropping on the cumulative $\mathrm{N}$-uptake by the cotton seedlings are shown at the end of the intercrop period, i.e. June 14 (49 DAS) in 2002, June 10 (46 DAS) in 2003 and June 17 (53 DAS) in 2004 (Fig. 4). All intercropping systems show large and significant differences in relative $\mathrm{N}$-yield per plant with the monoculture, ranging from 0.18 to 0.48 over 3 years, 2002-2004. There are no significant differences between intercropping systems, except for the significantly lower $\mathrm{N}$-accumulation in the $3: 1$ system compared to the other intercropping systems in 2003.

$\mathrm{N}$ accumulation in cotton at the end of the wheat growing period is a reflection of the competitive effects of the wheat on the cotton, reflected in the Ncontent of the above-ground biomass (Fig. 5). The competitive effect is closely related to the width of the space between the wheat strips, which is narrowest in the $3: 1$ system $(60 \mathrm{~cm})$, wider in $3: 2(80 \mathrm{~cm})$ and $4: 2$ $(90 \mathrm{~cm})$, and widest in $6: 2$ system $(100 \mathrm{~cm}$; Fig. 1$)$. Correspondingly, the N-content of cotton seedlings is the least in the $3: 1$ system, greater in $3: 2$, still greater in the 4:2 and 6:2 systems, and greatest in the cotton monoculture (Fig. 5). Averaged over 3 years the $\mathrm{N}$ content of cotton seedlings in intercrops ranged from about 3.2 to $3.4 \%$, which is significantly lower $(P<$ $0.01)$ than in monoculture $(3.6 \%)$. Cotton had a significantly lower $\mathrm{N}$-content in the $3: 1$ system than in any other intercropping system $(P<0.05)$. Thus wheat exhibited significant effects on $\mathrm{N}$-uptake of cotton seedlings during intercropping.

Nitrogen dilution curves for wheat and cotton

Nitrogen dilution curves of wheat and cotton are shown in Fig. 6a and b. Wheat showed an ongoing decline in leaf nitrogen content with increase in total dry weight. The dilution was less rapid in the monocrop of wheat than in intercrops, possibly resulting from a lesser dry weight increase as a result of a stronger competition for light compared to wheat grown in intercrop strips, where there is sideways incidence of light. Leaf nitrogen content in cotton decreased rapidly while the crop progressed from the seedling stage to an aboveground dry mass of $200 \mathrm{~g} \mathrm{~m}^{-2}$, but it remained
Fig. 6 Relationship between above-ground dry mass and nitrogen content for wheat (a) and cotton (b) in the intercrops and the monocultures in 2002

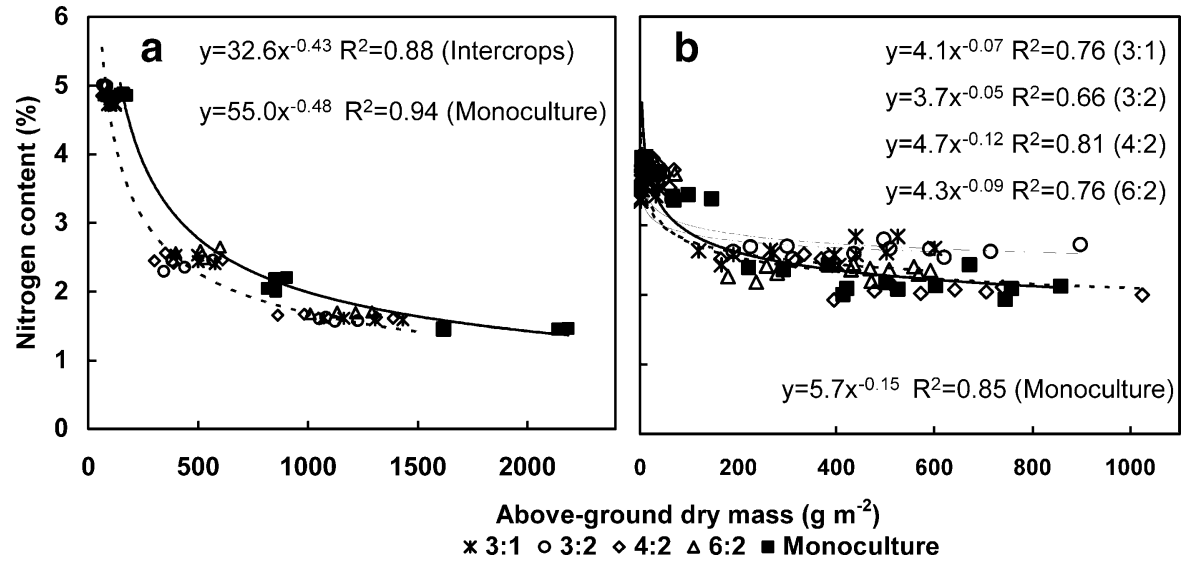




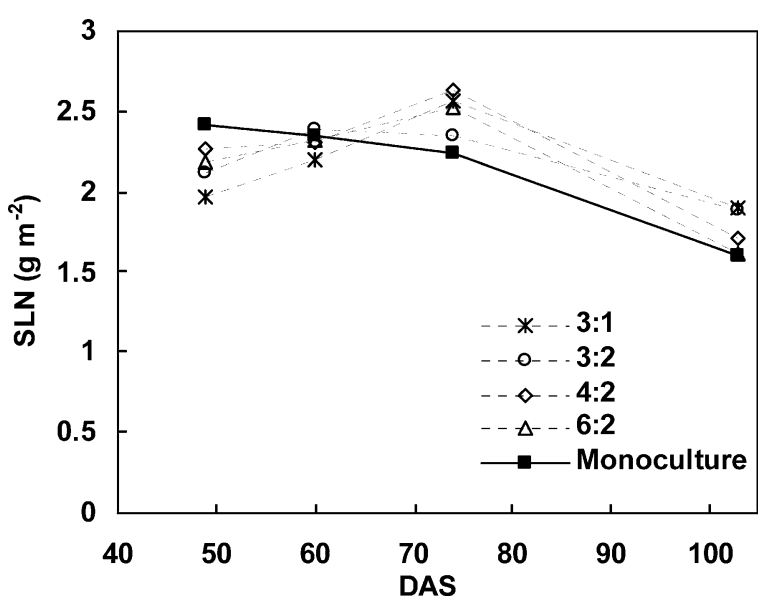

Fig. 7 Specific leaf nitrogen content (SLN) of cotton before anthesis in the intercropping systems and the monoculture in 2002

relatively constant from then on. The level at which $\mathrm{N}$ content leveled off was higher in the cotton than in the wheat, and the dilution was somewhat less in the cotton plants of the 3:2 system than of the other systems.

Trends in specific leaf nitrogen content

The seasonal dynamics in crop nitrogen content of intercropped and monocrop cotton were reflected in the specific leaf nitrogen content (SLN); three phases are distinguished (Fig. 7). The first phase of cotton seedling growth; because of retarded growth, SLN at 50 DAS (time of wheat harvest) was significantly lower in intercrops than in sole cotton. During the second phase, from 50 to 75 DAS, the SLN of the intercrops recovered, exceeding the SLN of the monoculture. During the third phase, from DAS 75 to cotton harvest, the SLN of intercrops stayed higher than in the monocrop, because more nitrogen was accumulated in the vegetative organs of intercropped cotton and crop senescence was delayed. The delayed senescence of leaves yielded some increase of dry mass, but did not compensate for the delay in growth during the early stages. These findings show that intercropped cotton accumulates more $\mathrm{N}$ per unit of biomass than sole cotton.

\section{Discussion and conclusions}

Nitrogen use at the crop level

$\mathrm{N}$ yield of wheat ranged from 130 to $205 \mathrm{~kg} \mathrm{ha}^{-1}$ in intercrops, which is $62-84 \%$ of the monoculture.
The total $\mathrm{N}$ uptake of wheat ranged from 203 to $288 \mathrm{~kg} \mathrm{ha}^{-1}$ in the monoculture which corresponds to the reported $257 \mathrm{~kg} \mathrm{ha}^{-1} \mathrm{~N}$ uptake of wheat at about $8 \mathrm{t} \mathrm{ha}^{-1}$ grain yield, averaged over five regions in China (Liu et al. 2006).

The values for total $\mathrm{N}$ uptake of sole cotton, ranging from 110 to $127 \mathrm{~kg} \mathrm{ha}^{-1}$ in 2002, 2003 and 2004, were within the range $\left(67-403 \mathrm{~kg} \mathrm{ha}^{-1}\right)$ reported by Rochester (2007), but lower than found by Ishaq et al. (2001) and Sainju et al. (2006). Total N uptake did not differ from the monoculture in any intercropping system in 2002; however, in 2003 similar N uptake as in monoculture was only found in intercropping systems $3: 2$ and $4: 2$ and a lower uptake in the $3: 1$ and $6: 2$ systems. In intercropping system $6: 2$ the crop failed to close the canopy and therefore light interception and crop growth were reduced; as a consequence the $\mathrm{N}$ yield in 2003 and 2004 was significantly less $(48 \%)$ than in the monoculture.

The different responses between seasons and within intercropping systems are strongly associated with the degree of competition during the cotton seedling stage and with canopy development after the wheat harvest when the full space can be used by the cotton crop. The nitrogen uptake of intercropped cotton was only $15-45 \%$ of the sole cotton at the time of the wheat harvest. After the wheat harvest, the nitrogen uptake in the intercropping systems recovered. These findings suggest that during the reproductive phase, the delayed fruiting and boll formation resulted in a weaker sink, and therefore more assimilates were retained in the vegetative parts. As a consequence the leaves could stay green for a longer period of time.

The physiological nitrogen use efficiency (IE) of wheat was not much affected by intercropping, but the $\mathrm{N}$ and grain yield per unit homogenized land area were strongly associated with the plant densities. Internal efficiencies (IE) of wheat in intercrops and the monocrop were similar except in the 3:2 system that showed higher values; IE of wheat ranged from 26.5 to $29.0 \mathrm{~kg} \mathrm{~kg}^{-1}$ on average over 3 years. IE was higher in 2004 due to a higher harvest index (HI). A higher $\mathrm{HI}$ in intercrops may be explained from a border row effect as a result of border plants receiving more light. Liu et al. (2006) reported that IE of wheat ranged from 19.8 to $66.4 \mathrm{~kg} \mathrm{~kg}^{-1}$ in China based on estimates by the QUEFTS model. Our results were within the range of $25.5-30.5 \mathrm{~kg} \mathrm{~kg}^{-1}$. 
Table $6 \mathrm{~N}$ balance sheet including the $\mathrm{N}$ residues and $\mathrm{N}$ excess in the intercropping and monocropping systems in 2 years (Exp. 1)

\begin{tabular}{|c|c|c|c|c|c|c|}
\hline \multirow[t]{2}{*}{ Cropping system } & \multicolumn{3}{|c|}{$\mathrm{N}$ residue $\left(\mathrm{g} \mathrm{m}^{-2}\right)^{\mathrm{a}}$} & \multicolumn{3}{|c|}{$\mathrm{N}$ excess $\left(\mathrm{g} \mathrm{m}^{-2}\right)^{\mathrm{b}}$} \\
\hline & Wheat & Cotton & Total & Wheat & Cotton & Total \\
\hline \multicolumn{7}{|l|}{$-2002 / 03-$} \\
\hline $3: 1$ & 8.9 ac & $4.5 \mathrm{ab}$ & $13.4 \mathrm{a}$ & $24.0 \mathrm{a}$ & $16.8 \mathrm{ab}$ & $40.8 \mathrm{a}$ \\
\hline $3: 2$ & $5.9 \mathrm{~b}$ & $5.3 \mathrm{ab}$ & $11.2 \mathrm{a}$ & $25.1 \mathrm{~b}$ & $15.7 \mathrm{a}$ & $40.8 \mathrm{a}$ \\
\hline $4: 2$ & $7.0 \mathrm{ab}$ & $6.2 \mathrm{a}$ & $13.2 \mathrm{a}$ & $24.5 \mathrm{ab}$ & $16.2 \mathrm{ab}$ & $40.7 \mathrm{a}$ \\
\hline $6: 2$ & $8.4 \mathrm{ac}$ & $2.4 \mathrm{~b}$ & $10.8 \mathrm{a}$ & $24.4 \mathrm{ab}$ & $17.3 \mathrm{~b}$ & $41.7 \mathrm{a}$ \\
\hline Monoculture & $10.0 \mathrm{c}$ & $4.9 \mathrm{ab}$ & - & $21.9 \mathrm{c}$ & $14.0 \mathrm{c}$ & - \\
\hline SE & 0.8 & 0.9 & 1.3 & 0.2 & 0.4 & 0.4 \\
\hline \multicolumn{7}{|l|}{$-2003 / 04-$} \\
\hline $3: 1$ & $8.9 \mathrm{a}$ & $5.1 \mathrm{ab}$ & $14.0 \mathrm{a}$ & $21.1 \mathrm{a}$ & $18.6 \mathrm{a}$ & $39.7 \mathrm{a}$ \\
\hline $3: 2$ & $6.9 \mathrm{a}$ & $6.0 \mathrm{~b}$ & $12.9 \mathrm{ab}$ & $22.5 \mathrm{~b}$ & $17.1 \mathrm{~b}$ & $39.6 \mathrm{a}$ \\
\hline $4: 2$ & $8.9 \mathrm{a}$ & $3.2 \mathrm{ac}$ & $12.1 \mathrm{ab}$ & $22.7 \mathrm{~b}$ & $18.1 \mathrm{ab}$ & $40.8 \mathrm{~b}$ \\
\hline $6: 2$ & $7.3 \mathrm{a}$ & $1.7 \mathrm{c}$ & $9.0 \mathrm{~b}$ & $22.4 \mathrm{~b}$ & $18.6 \mathrm{a}$ & $41.0 \mathrm{~b}$ \\
\hline Monoculture & $13.4 \mathrm{~b}$ & $3.7 \mathrm{ac}$ & - & $19.1 \mathrm{c}$ & $15.4 \mathrm{c}$ & - \\
\hline SE & 1.0 & 0.7 & 1.3 & 0.3 & 0.4 & 0.3 \\
\hline
\end{tabular}

${ }^{\mathrm{a}} \mathrm{N}$ residue $=\mathrm{N}$ yield $-\mathrm{N}$ removal; where $\mathrm{N}$ removal was derived from wheat grain and cotton seed yield and an estimated $\mathrm{N}$ content of $1.97 \%$ and $2.5 \%$ for wheat and cotton, respectively.

${ }^{\mathrm{b}} \mathrm{N}$ excess $=(\mathrm{N}$ applied + soil indigenous $\mathrm{N})$ minus $\mathrm{N}$ removal; where soil indigenous $\mathrm{N}$ was estimated by extrapolation of the linear relationship between $\mathrm{N}$ applied and total $\mathrm{N}$ uptake.

Based on lint yields IE of cotton ranged from 6.4 to $8.2 \mathrm{~kg}$ lint per $\mathrm{kg} \mathrm{N}$ uptake in intercrops in 3 years, which was significantly lower $(P<0.05)$ than in monoculture $\left(9.7 \mathrm{~kg} . \mathrm{kg}^{-1}\right)$ except in the $6: 2$ system. Compared to the monoculture, the lower IE of intercropped cotton was due to a lower HI $(18 \%)$ as a result of the delay in growth and development during the early growth stages (Zhang et al. 2007b). The variation in IE of intercropped cotton under various environmental condition (years) indicates that genotype $\times$ environment interactions may play an important role. Thus, a more detailed analysis of the $\mathrm{N}$ dynamics of various genotypes of cotton under contrasting environmental conditions is needed.

Nitrogen dynamics at the plant level

Plant N uptake is co-regulated by soil $\mathrm{N}$ supply and shoot growth, as concluded by Lemaire et al. (2007) based on studies under different environments (temperate and subtropical) with various crop species $\left(\mathrm{C}_{3}\right.$ and $\mathrm{C}_{4}$ ). The relationship between $\mathrm{N}$ uptake and biomass accumulation reflects the feed-back regulation of $\mathrm{N}$ absorption capacity of roots by shoot growth itself under non-limiting $\mathrm{N}$ supply. During the intercropping period, the nitrogen content of cotton seedlings was significantly lower than in the mono- culture. We conclude that intercropping decreased $\mathrm{N}$ uptake of cotton seedlings strongly during the intercropping period. Cotton plants compensate with extra $\mathrm{N}$ uptake at later growth stages for a delay in development as a consequence of shading in the seedling phase.

The coefficient $b_{c}$ of the $\mathrm{N}$ dilution curve in sole wheat was 0.48 , which was consistent with the study of Flenet et al. (2006). The $\mathrm{N}$ demand per unit biomass of cotton in intercrops was greater than in the monoculture. The specific leaf nitrogen content (SLN) of cotton in intercrops ranged from 2.0 to $2.3 \mathrm{~g} \mathrm{~m}^{-2}$. The relationship between SLN and radiation use efficiency (RUE) for cotton is consistent with other species (Milroy and Bange 2003). In cotton a linear increase of RUE was found for leaf $\mathrm{N}$ contents ranging from 2 to 5\% (Sadras 1996). Milroy and Bange (2003) reported also that leaf assimilate rates were about 3 times higher at SLN-values within a range from 2.78 to $4.32 \mathrm{~g} \mathrm{~m}^{-2}$ compared to $1.45 \mathrm{~g} \mathrm{~m}^{-2}$. This corresponds with the findings of Reddall et al. (2004); they reported that leaf assimilate rates rapidly increased within a range from 0.9 to $2.5 \mathrm{~g} \mathrm{~m}^{-2}$. Thus the lower SLN values in the $3: 1$ system are likely to have resulted in a reduced light use efficiency. The recovery of the nitrogen content in cotton biomass after the intercropping period, is in good agreement with 
compensatory effects documented for cotton after loss of reproductive organs (Sadras 1995). Our results confirm the compensatory effect for cotton with a delay in development in wheat-cotton intercropping systems.

Relative $\mathrm{N}$ yields and $\mathrm{N}$ balance at the system level

We found that the relative nitrogen yield total (RNT) in the intercropping systems ranged from 1.4 to 1.7 ; only the RNT of the 6:2 system was significantly lower. Compared to the land equivalent ratios (LER), which ranges on average from 1.3 to 1.4 in intercropping systems (Zhang et al. 2007a), the RNT is $8-21 \%$ higher. It was concluded that cotton wheat relay intercropping systems utilize $\mathrm{N}$ less efficiently than the monocrops at the system level.

In our experiment the $\mathrm{N}$-doses applied in the intercropping systems (range: $302-412 \mathrm{~kg} \mathrm{ha}^{-1}$ ) and in the monocultures (for wheat: 124-211 kg ha ${ }^{-1}$ and for cotton $121-187 \mathrm{~kg} \mathrm{ha}^{-1}$ ) were less than in farmers' practice. The conventional N-fertilizer doses in farmers' practice in the Yellow River region amounted to $375 \mathrm{~kg} \mathrm{ha}^{-1}$ in wheat and $360 \mathrm{~kg} \mathrm{ha}^{-1}$ in cotton (Zhen et al. 2006). The soil indigenous $\mathrm{N}$ estimated in this study ranged from 115 to $141 \mathrm{~kg} \mathrm{ha}^{-1}$ for wheat, which corresponds quite well with the $135 \mathrm{~kg} \mathrm{ha}^{-1}$ reported for the same region (Liu et al. 2006). The Nexcess (Table 6) derived from the $\mathrm{N}$ balance sheet calculated as $\mathrm{N}$ input (applied plus soil indigenous $\mathrm{N}$ ) minus $\mathrm{N}$ removal by wheat grain and seed cotton ranged from 400 to $410 \mathrm{~kg} \mathrm{ha}^{-1}$ in the intercropping systems, which was much higher than in sole cotton $\left(147 \mathrm{~kg} \mathrm{ha}^{-1}\right)$ and wheat $\left(205 \mathrm{~kg} \mathrm{ha}^{-1}\right)$. Thus, more $\mathrm{N}$ in the intercropping systems was prone to losses by leaching or other processes than in the sole cotton system. In both systems, excessive $\mathrm{N}$ is being applied in practice, resulting in unnecessarily high input costs and environmental pollution.

The total $\mathrm{N}$ content of the soil in a $60 \mathrm{~cm}$ soil profile increased from $0.82-0.89 \mathrm{~g} \mathrm{~kg}^{-1}$ in Nov. 2001 (the beginning of experiment 1) to $0.91-0.96 \mathrm{~g} \mathrm{~kg}^{-1}$ in Dec. 2004 at the end of 3-years experimental period. This corresponds with an average increase in total soil $\mathrm{N}$ of about $600 \mathrm{~kg} \mathrm{ha}^{-1}$ over a period of 3 years. So, a substantial part of the excess $\mathrm{N}$ accumulated in the soil. The increase of soil $\mathrm{N}$ might be due to the full return of residues and immobilization of fertilizer $\mathrm{N}$. We concluded that the wheat- cotton intercropping system enriched soil N-status more than a sole cotton or wheat crop. Based on these findings, the $\mathrm{N}$ management of the intercropping systems as well as of monocrops should be improved by means of proper timing and demand-oriented dosing of $\mathrm{N}$ fertilization. Simple and robust crop simulation models and GIS can help to improve the decision support to farmers in developing more profitable and sustainable cotton cropping systems (McKinion et al. 2001).

Acknowledgements We acknowledge the financial support from the sandwich-PhD program of Wageningen University, the support through the Program for Changjiang Scholars and Innovative Research Teams in Universities (IRT0412), and the ' 948 ' project of Chinese Ministry of Agriculture.

\section{References}

Aggarwal PK, Garrity DP, Liboon SP, Morris RA (1992) Resource use and plant interactions in a rice-mungbean intercrop. Agron J 84:71-78

Baumann DT, Bastiaans L, Kropff MJ (2001) Competition and crop performance in a leek-celery intercropping system. Crop Sci 41:764-774

Blaise D, Bonde AN, Chaudhary RS (2005) Nutrient uptake and balance of cotton plus pigeonpea strip intercropping on rainfed vertisols of central India. Nutr Cycling in Agroecosyst 73:135-145

Booij R, Kreuzer ADH, Smit AL, van der Werf A (1996) Effect of nitrogen availability on dry matter production, nitrogen uptake and light interception of Brussels sprouts and leeks. Neth J Agric Sci 44:3-19

Flenet F, Guerif A, Boiffin J, Dorvillez D, Champolivier L (2006) The critical $\mathrm{N}$ dilution curve for linseed (Linum usitatissimum L.) is different from other C3 species. Europ J Agron 24:367-373

Haefele SM, Wopereis MCS, Ndiaye MK, Barro SE, Isselmod MO (2003) Internal nutrient efficiencies, fertilizer recovery rates and indigenous nutrient supply of irrigated lowland rice in Sahelian West Africa. Field Crops Res 80:19-32

Hauggaard-Nielsen H, Ambus P, Jensen ES (2001) Interspecific competition, $\mathrm{N}$ use and interference with weeds in peabarley intercropping. Field Crops Res 70:101-109

Ishaq M, Ibrahim M, Lal R (2001) Tillage effect on nutrient uptake by wheat and cotton as influenced by fertilizer rate. Soil \& Tillage Res 62:41-53

Justes E, Mary B, Meynard JM, Machet JM, Thelierhuche L (1994) Determination of a critical nitrogen dilution curve for winter-wheat crops. Ann Bot 74:397-407

Leigh RA, Johnston AE (1987) The usefulness of expressing nitrogen concentrations in crops on the basis of tissue water. J Sci Food Agric 38:317-318

Lemaire G, Oosterom E, Sheehy J, Jeuffroy MH, Massignam A, Rossato L (2007) Is crop N demand more closely 
related to dry matter accumulation or leaf area expansion during vegetative growth. Field Crops Res 100:91-106

Liu MQ, Yu ZR, Liu YH, Konijn NT (2006) Fertilizer requirements for wheat and maize in China: the QUEFTS approach. Nutr Cycling Agroecosyst 74:245-258

McKinion JM, Jenkins JN, Akins D, Turner SB, Willer JL, Jallas E, Whisler FD (2001) Analysis of a precision agriculture approach to cotton production. Comp Electron Agric 32:213-228

Milroy SP, Bange MP (2003) Nitrogen and light responses of cotton photosynthesis and implications for crop growth. Crop Sci 43:904-913

Ogg CL (1960) Determination of nitrogen by the microKjeldahl method. J Assoc Offic Agric Chem 43:689-693

Peng S, Bouman BAM (2007) Prospects for genetic improvement to increase lowland rice yields with less water and nitrogen. In: Spiertz JHJ, Struik PC, van Laar HH (eds) Scale and complexity in plant systems research: geneplant-crop relations. Springer, Wageningen UR Frontis Series Vol 21, pp 251-266

Reddall A, Sadras VO, Wilson LJ, Gregg PC (2004) Physiological responses of cotton to two-spotted spider mite damage. Crop Sci 44:835-846

Rochester IJ (2007) Nutrient uptake and export from an Australian cotton field. Nutr Cycling Agroecosyst 77: 213-223

Sadras VO (1995) Compensatory growth in cotton after loss of reproductive organs. Field Crops Res 40:1-18

Sadras VO (1996) Cotton responses to simulated insect damage: Radiation-use efficiency, canopy architecture and leaf nitrogen content as affected by loss of reproductive organs. Field Crops Res 48:199-208
Sainju UM, Whitehead WF, Singh BP, Wang S (2006) Tillage, cover crops, and nitrogen fertilization effects on soil nitrogen and cotton and sorghum yields. Europ J Agron 25:372-382

Spiertz JHJ, Vos J (2005) Nitrogen use efficiency and productivity of food crops in cereal-based agroecosystems. In: Zhaoliang Zhu, Katsu Minami, Guangxi Xing (eds) Contributed papers, 3rd Intern Nitrogen Conf, October 12-16, 2004, Nanjing, China. Science Press USA Inc., pp 259-265

Szumigalski AR, Van Acker RC (2006) Nitrogen yield and land use efficiency in annual sole crops and intercrops. Agron J 98:1030-1040

Willey RW (1979) Intercropping: its importance and research needs. I. Competition and yield advantages. Field Crops Abstr 32:1-10

Willey RW (1990) Resource use in intercropping systems. Agric Water Manage 17:215-231

Zhang F, Shen J, Li L, Liu X (2004) An overview of rhizosphere processes related with plant nutrition in major cropping systems in China. Plant Soil 260:89-99

Zhang L, van der Werf W, Zhang S, Li B, Spiertz JHJ (2007a) Growth, yield and quality of wheat and cotton in relay strip intercropping systems. Field Crops Res 103(3):178-188, DOI 10.1016/j.fcr.2007.1006.1002

Zhang L, van der Werf W, Zhang S, Li B, Spiertz JHJ (2007b) Cotton development and temperature dynamics in relay intercropping with wheat. Field Crops Res (Submitted)

Zhen L, Zoebisch MA, Chen GB, Feng ZM (2006) Sustainability of farmers' soil fertility management practices: a case study in the North China Plain. J Env Manage 79:409-419 